\title{
Calcium isotopes in cratonic mantle eclogites
}

\author{
KATIE SMART ${ }^{1}$, SEBASTIAN TAPPE ${ }^{2}$, ALAN B. \\ WOODLAND $^{3}$, CHRIS HARRIS ${ }^{4}$, NIKOLAUS GUSSONE ${ }^{5}$ \\ AND ANTONIO SIMONETTI ${ }^{6}$
}

${ }^{1}$ University of the Witwatersrand

${ }^{2}$ University of Johannesburg

${ }^{3}$ Goethe University of Frankfurt

${ }^{4}$ University of Cape Town

${ }^{5}$ Westfälische-Wilhelms Universität

${ }^{6}$ University of Notre Dame

Presenting Author: katie.smart2@wits.ac.za

Eclogites sampled from the cratonic lithospheric mantle by kimberlite volcanism often reveal Mesoarchean to Paleoproterozoic ages complementary to known magmatic and collisional events recorded in the overlying early continental crust (1). This coincidence of ages, combined with the elemental and stable isotopic characteristics of mantle eclogites, has resulted in a paradigm where ancient oceanic lithosphere was subducted beneath the emerging continents contributing to continental growth during the Precambrian (2). The eclogitic components of former subducted oceanic slabs are compositionally complementary to Archean TTG granitoids, which further link cratonic mantle eclogites to early continent formation in the form of magmatic residues of the first felsic continental crust (3).

Here we investigate the utility of stable $\mathrm{Ca}$ isotopes in the argument of a crustal origin for mantle eclogites (4). We analyzed the $\mathrm{Ca}$ isotopic compositions of both garnet and clinopyroxene for eclogite xenoliths from the Bellsbank kimberlite, Kaapvaal craton. The Bellsbank eclogites have Archean formation ages, and show trace element and oxygen isotope evidence for recycled crustal protoliths. Bulk eclogite $\delta^{44 / 40} \mathrm{Ca}$ values (proportionally calculated from garnet and clinopyroxene) range from +0.28 to $+1.56 \%$. Most eclogite samples have $\delta^{44 / 40} \mathrm{Ca}$ values between +0.70 and $+1.04 \%$ that are similar to that of depleted mantle and MORB, but importantly overlap with the range of $\delta^{44 / 40} \mathrm{Ca}$ values known for altered oceanic basalts and gabbros. There is a general negative correlation of Bellsbank garnet $\delta^{44 / 40} \mathrm{Ca}$ and $\delta^{18} \mathrm{O}$, suggesting that seawater alteration has overprinted both the stable oxygen and calcium isotopic compositions of the crustal protoliths. The most depleted $\mathrm{Ca}$ isotopic compositions of the eclogite suite may be attributed to metasomatism by carbonatitic melts that are characterized by low $\delta^{44 / 40} \mathrm{Ca}$ values. In contrast, eclogites with $\delta^{44 / 40} \mathrm{Ca}$ values above $1.3 \%$ may record melt-induced isotopic fractionation, whereby mantle eclogite components may be the residual source of TTG-like felsic magmas characterized by low $\delta^{44 / 40} \mathrm{Ca}(5)$.

1 Shirey et al., (2004) Lithos 77, 923 - 944.

2 Jacob (2004). Lithos 77, 295 - 316.

3 Ireland et al., (1994). Earth Planet. Sci. Letts. 128,199-213.

4 Smart et al., (2021). Earth Planet. Sci. Letts. 556, 116720.

5 Wang et al., (2019). Geochim.Cosmochim.Acta 259, 37-52. 